\title{
Exploiting Bidirectional Electrocatalysis by a Nanoconfined Enzyme Cascade to Drive and Control Enantioselective Reactions
}

\author{
Lei Wan, ${ }^{1}$ Rachel S. Heath, ${ }^{2}$ Clare F. Megarity, ${ }^{1}$ Adam J. Sills, ${ }^{1}$ Ryan A. Herold, ${ }^{1}$ \\ Nicholas J. Turner, ${ }^{2^{*}}$ and Fraser A. Armstrong ${ }^{1^{*}}$ \\ ${ }^{1}$ Department of Chemistry, University of Oxford, South Parks Road, Oxford, OX1 3QR, UK \\ ${ }^{2}$ School of Chemistry, University of Manchester, Manchester Institute of Biotechnology, \\ 131 Princess Street, Manchester M1 7DN, UK \\ nicholas.turner@manchester.ac.uk \\ fraser.armstrong@chem.ox.ac.uk
}

\section{Content}

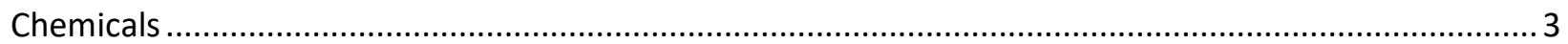

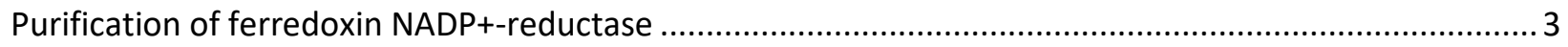

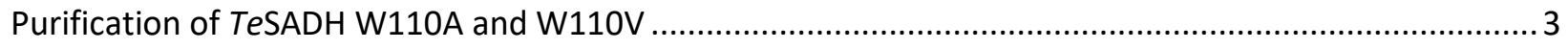

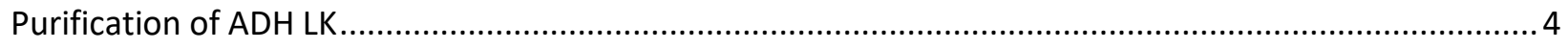

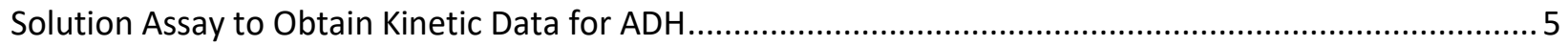

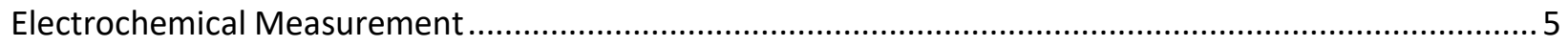

Fabrication of ITO/Ti-foil, ITO/ITO-glass and ITO/graphite Electrode ............................................... 6

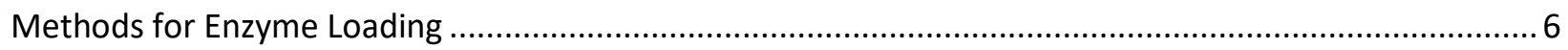

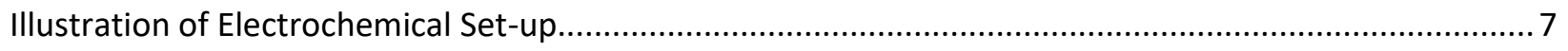

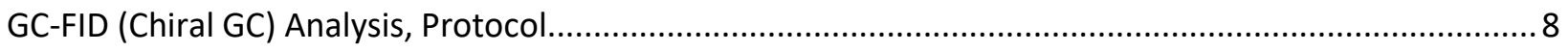

Data for (FNR + TeSADH W110A)-catalyzed Reduction of 4-phenyl-2-butanone.................................... 9

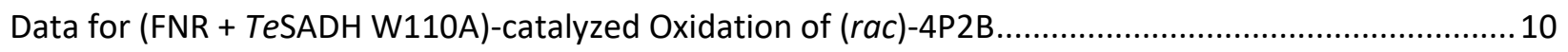

Solution Assays of the TeSW110A-catalysed Racemization ........................................................... 11

Data for (FNR + ADH LK)-catalyzed Electrochemical Reduction of 4-phenyl-2-butanone.........................12 


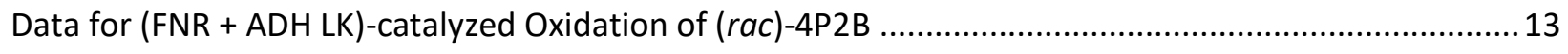

Data for (FNR + TeSADH W110V)-catalyzed Reduction of 4-phenyl-2-butanone...................................14

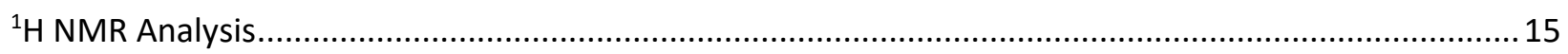

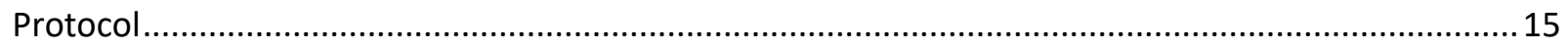

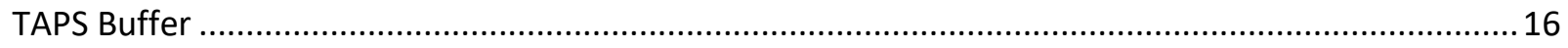

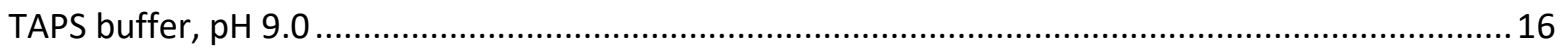

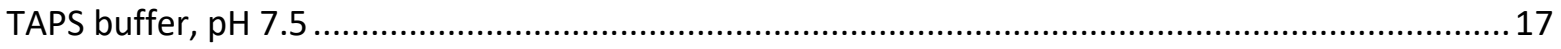

Standard Solution of 4-phenyl-2-butanol in TAPS Buffer at pH 9.0................................................. 18

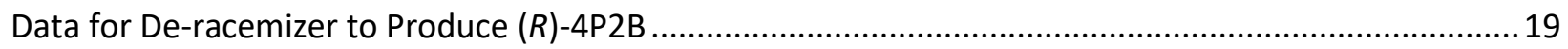

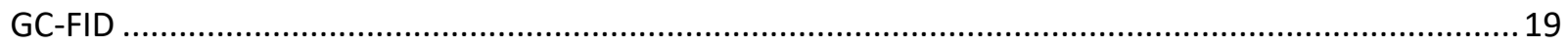

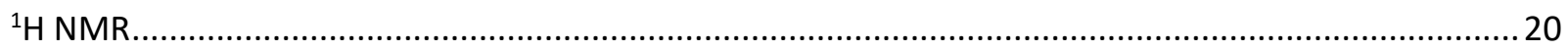

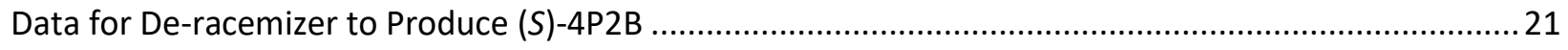

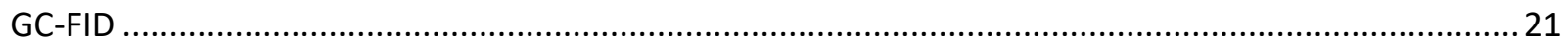

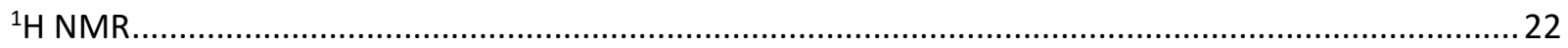




\section{Chemicals}

(rac)-4-phenyl-2-butanol (Alfa Aesar, 98\%), (S)-4-phenyl-2-butanol (ChemCruz, 98\%, ee > 98\%), 4-phenyl2-butanone (Sigma-Aldrich, 98\%), NADPH (tetrasodium salt, 93\%, Melford), NADP ${ }^{+}$(monosodium salt, 98\%, Melford), indium tin oxide powder (<50 nm particle size, Sigma-Aldrich), acetone (ACS Reagent), [tris(hydroxymethyl)methylamino]-propanesulfonic acid (TAPS, Melford, 99\%), iodine (Alfa Aesar), and (Trimethylsilyl)propionic-2,2,3,3-d4 acid sodium salt (TMSP, Alfa Aesar, 98\%) were purchased and used without further purification. ( $R$ )-4-phenyl-2-butanol (ChemCruz, 98\%, ee >98\%) was purified by Dr. Carole Bataille before use to remove traces of unknown reducible materials that would convolute the results by contributing to the reduction current during electrochemical measurements.

\section{Purification of ferredoxin NADP+-reductase}

The protocol is available in reference C. F. Megarity et al. ${ }^{1}$

\section{Purification of TeSADH W110A and W110V}

The pET28 vectors containing the genes encoding the $110 \mathrm{~A}$ and $110 \mathrm{~V}$ variants of the secondary alcohol dehydrogenase from Thermoanerobacter ethanolicus 39E (with a His-tag encoded at the N-terminal and also the genes to confer kanamycin resistance), were transformed into commercially available $E$. Coli. BL 21 cells (New England Biolabs). Colonies were grown on Luria-Bertani (LB) agar plates, containing $30 \mu \mathrm{g}$ $\mathrm{mL}^{-1}$ kanamycin, overnight. A single colony was used to inoculate $100 \mathrm{~mL}$ of $\mathrm{LB}\left(25 \mathrm{gL}^{-1}\right)$ containing kanamycin $\left(30 \mu \mathrm{g} \mathrm{m}^{-1}\right)$ and left to grow overnight at $37^{\circ} \mathrm{C}$ and $200 \mathrm{rpm}$. The overnight culture was then diluted into TB autoinduction media (Formedium) containing $30 \mu \mathrm{g} \mathrm{mL}^{-1}$ kanamycin ( $15 \mathrm{~mL}$ of culture into six $500 \mathrm{~mL}$ portions) and grown at $37^{\circ} \mathrm{C}$ and $250 \mathrm{rpm}$ for $16-20$ hours. The cells were harvested by centrifugation for $30 \mathrm{~min}$ at $4^{\circ} \mathrm{C}$ and $4000 \mathrm{rpm}$. The cell pellets were resuspended in phosphate buffer (100 mM), pH 7.7, supplemented with $300 \mathrm{mM} \mathrm{NaCl}, 20 \mathrm{mM}$ imidazole and 10\% glycerol. The cells were then disrupted using a French press and the suspension was then centrifuged for 1 hour at $45000 \mathrm{rpm}$ and $4^{\circ} \mathrm{C}$. The resulting supernatant containing the overexpressed protein, was passed through a $0.45 \mu \mathrm{m}$ filter and collected. This was loaded onto a $5 \mathrm{~mL}$ His-Select ${ }^{\mathrm{TM}} \mathrm{Ni}^{2+}$ column (GE Healthcare) using an ÄKTA protein purification system; the column was washed with 10 column volumes of buffer $\mathrm{A}$ (pH 7.7, $100 \mathrm{mM}$ phosphate, $300 \mathrm{mM} \mathrm{NaCl}, 20 \mathrm{mM}$ imidazole and $1 \mathrm{mM}$ dithiothreitol (DTT)) and then eluted in the same 
buffer by a linear gradient of imidazole to reach 300 mM (buffer B: pH 7.7, 100 mM phosphate, 300 mM $\mathrm{NaCl}, 300 \mathrm{mM}$ imidazole and $1 \mathrm{mM}$ DTT) over 10 column volumes. To remove imidazole, the protein was dialyzed overnight against Tris buffer (50 mM), pH 8.0 supplemented with 1 mM DTT. The protein was aliquoted, flash frozen in liquid nitrogen and stored at $-80^{\circ} \mathrm{C}$.

\section{Purification of ADH LK}

The gene sequence encoding the $(R)$-selective secondary alcohol dehydrogenase from Lactobacillus kefir was available from the reference $A$. Weckbecker et $a l^{2}$ and was subsequently synthesised by GeneArt, Life Technologies, Thermo Scientific. The gene was then inserted into a vector, which also encoded a hexa HIStag and the genes to confer ampicillin resistance, using ligation independent cloning (LIC) (aLICator, Thermo Scientific, N-terminal His-tag/EK, \#K1251); the sequence was confirmed by Source Bioscience. The resulting plasmid was then transformed into E. Coli. BL 21 (New England Biolabs) cells and grown overnight on LB agar plates supplemented with ampicillin to a final concentration of $0.27 \mathrm{mM}$. A flask containing $100 \mathrm{~mL} \mathrm{LB}\left(25 \mathrm{~g} \mathrm{~L}^{-1}\right)$ supplemented with ampicillin $(0.27 \mathrm{mM})$, was inoculated with a single positive colony and grown overnight at $37{ }^{\circ} \mathrm{C}$ and $250 \mathrm{rpm}$. The overnight culture was diluted into six 500 $\mathrm{mL}$ portions of LB $\left(25 \mathrm{~g} \mathrm{~L}^{-1}\right)$ supplemented with ampicillin $(0.27 \mathrm{mM})$; approximately $15 \mathrm{~mL}$ of overnight culture was added to each $500 \mathrm{~mL}$ portion. The cells were grown at $37^{\circ} \mathrm{C}$ and $200 \mathrm{rpm}$ for $2-2.5$ hours until approximately mid-log phase upon which IPTG was added to a final concentration of $1.3 \mathrm{mM}$. The temperature was reduced to $30{ }^{\circ} \mathrm{C}$ and overexpression of the protein was allowed to continue for approximately 20 hours (at $250 \mathrm{rpm}$ ). The cell cultures were then centrifuged at $6000 \mathrm{rpm}$ for 30 minutes at $4{ }^{\circ} \mathrm{C}$ and the cell pellets resuspended in cold buffer $(50 \mathrm{mM}$ Tris, $500 \mathrm{mM} \mathrm{NaCl}, 1 \mathrm{mM} \mathrm{MgCl}, 10 \%$ glycerol, $\mathrm{pH}$ 8.0) before disruption using a French press. The resulting suspension was then centrifuged for 1 hour at $45000 \mathrm{rpm}$ and $4{ }^{\circ} \mathrm{C}$ and the supernatant collected and loaded onto a $5 \mathrm{~mL} \mathrm{His-Select}{ }^{\mathrm{TM}} \mathrm{Ni}^{2+}$ column (GE Healthcare) using an ÄKTA protein purification system; the column was washed with 10 column volumes of buffer A ( $50 \mathrm{mM}$ Tris, $500 \mathrm{mM} \mathrm{NaCl}, 1 \mathrm{mM} \mathrm{DTT}, 1 \mathrm{mM} \mathrm{MgCl}$, $\mathrm{pH}$ 8.0). The enzyme was eluted in the same buffer by a linear gradient of imidazole to reach $250 \mathrm{mM}$ (buffer B: $50 \mathrm{mM}$ Tris, $500 \mathrm{mM} \mathrm{NaCl}, 1 \mathrm{mM}$ DTT, $1 \mathrm{mM} \mathrm{MgCl}$, 250 mM imidazole, pH 8.0) over 10 column volumes. The protein was concentrated using a $10 \mathrm{kDa}$ molecular weight cut-off spin column (GE Healthcare) to have a final concentration $\sim 5-10 \mathrm{mg} \mathrm{mL}^{-1}$ and dialysed overnight at $4{ }^{\circ} \mathrm{C}$ against Tris buffer $(50 \mathrm{mM}, \mathrm{pH} 8.0$ ) supplemented with $1 \mathrm{mM} \mathrm{MgCl} 2$ and $1 \mathrm{mM}$ DTT. The purified enzyme was aliquoted and flash frozen in liquid nitrogen before storing at $-80{ }^{\circ} \mathrm{C}$. 


\section{Solution Assay to Obtain Kinetic Data for ADH}

Solution assays to monitor ADH-catalysed alcohol oxidation ((S)-4-phenyl-2-butanol at pH 9.0 and (R)-4phenyl-2-butanol as substrates) and ketone reduction (4-phenlyl-2-butanone as substrate) at $\mathrm{pH} 7.5$ with substrate concentration ranging from $0.09-10 \mathrm{mM}$ were carried out using UV-Vis spectroscopy (PerkinElmer Lambda 19 UV-Vis; quartz cuvette). Activity was monitored (in triplicate) by measuring the consumption (for reduction of ketone) or production (for oxidation of alcohol) of NADPH over time; initial rates were obtained from the linear decrease or increase in $A_{340}$. Non-linear curve-fitting was performed using the 'Isqcurvefit' nonlinear model of MATLAB using the modified version of the Michaelis-Menten equation, ${ }^{3}$

$v=\frac{v_{\max }[\mathrm{s}]}{\mathrm{K}_{\mathrm{m}}+[\mathrm{s}]+\frac{[\mathrm{s}]^{2}}{\mathrm{~K}_{\mathrm{i}}}}$

where $v$ is the reaction rate, $K_{\mathrm{m}}$ is the Michaelis-Menten constant, [S] is the concentration of substrate (herein (S)-4P2B, $(R)-4 \mathrm{P} 2 \mathrm{~B}$, or 4-phenyl-2-butanone) and $K_{\mathrm{i}}$ is the substrate inhibition constant. The equation for substrate inhibition was chosen since preliminary results for TeSADH indicated this phenomenon. This effect was especially notable when using ketone as the substrate for TeSADH. Experimental conditions: $25 \pm 2^{\circ} \mathrm{C},\left[\mathrm{NADP}^{+}\right]=300 \mu \mathrm{M}$ (for alcohol oxidation), [NADPH] $=200 \mu \mathrm{M}$ (for ketone reduction), reaction volume $=400 \mu \mathrm{L}$, buffer for alcohol oxidation: $\mathrm{pH}$ 9.0, $50 \mathrm{mM}$ TAPS, $1 \mathrm{mM}$ $\mathrm{MgCl}_{2}$, buffer for ketone reduction: pH $7.550 \mathrm{mM}$ TAPS, $1 \mathrm{mM} \mathrm{MgCl} 2,25 \mathrm{mM} \mathrm{NaCl}$.

\section{Electrochemical Measurement}

The cyclic voltammetry and chronoamperometry techniques were carried out using the Palmsens or the PStrace potentiostats. A saturated calomel electrode (SCE) and a $\mathrm{Ag} / \mathrm{AgCl}$ (in $3 \mathrm{M} \mathrm{KCl}$ ) electrode were both used in this paper. The conversion relation between the standard hydrogen electrode (SHE) and the SCE or $\mathrm{Ag} / \mathrm{AgCl}$ (in $3 \mathrm{M} \mathrm{KCl})$ at $298 \mathrm{~K}\left(25^{\circ} \mathrm{C}\right)$ are as follows:

$$
\begin{gathered}
E_{S H E}=E_{S C E}+0.242 \mathrm{~V} \\
E_{S H E}=E_{A g / A g C l}+0.211 V
\end{gathered}
$$




\section{Fabrication of ITO/Ti-foil, ITO/ITO-glass and ITO/graphite Electrode}

The solution for electrophoresis contained iodine $(0.01 \mathrm{~g})$, acetone $(20 \mathrm{~mL})$ and ITO nanopowder $(0.02 \mathrm{~g})$. The detailed process for making the solution and electrophoresis set-up is described in the references. ${ }^{4,5}$ In this paper, electrophoretic deposition of the ITO (to form the nanoporous layer) on either the graphite or ITO glass supports, was carried out for 6 minutes. While for the double sided Ti foil, electrophoretic deposition was carried out for at least 6 minutes per side.

\section{Methods for Enzyme Loading}

In this paper, two enzyme loading methods were employed: (i) by placing the ITO/support electrode into a vial containing $2.5 \mathrm{~mL}$ of a dilute mixture of FNR and ADH solution overnight, during which time the solution was gently stirred, (ii) by dropcasting a concentrated $10 \mu \mathrm{L}$ aliquot containing FNR and ADH onto the ITO/support electrode and incubating for 15-30 minutes ensuring it did not dry out. Importantly, before use, electrodes were rinsed thoroughly by buffer to ensure all unbound enzyme was rinsed away so that none would be present in the cell solution. 


\section{Illustration of Electrochemical Set-up}

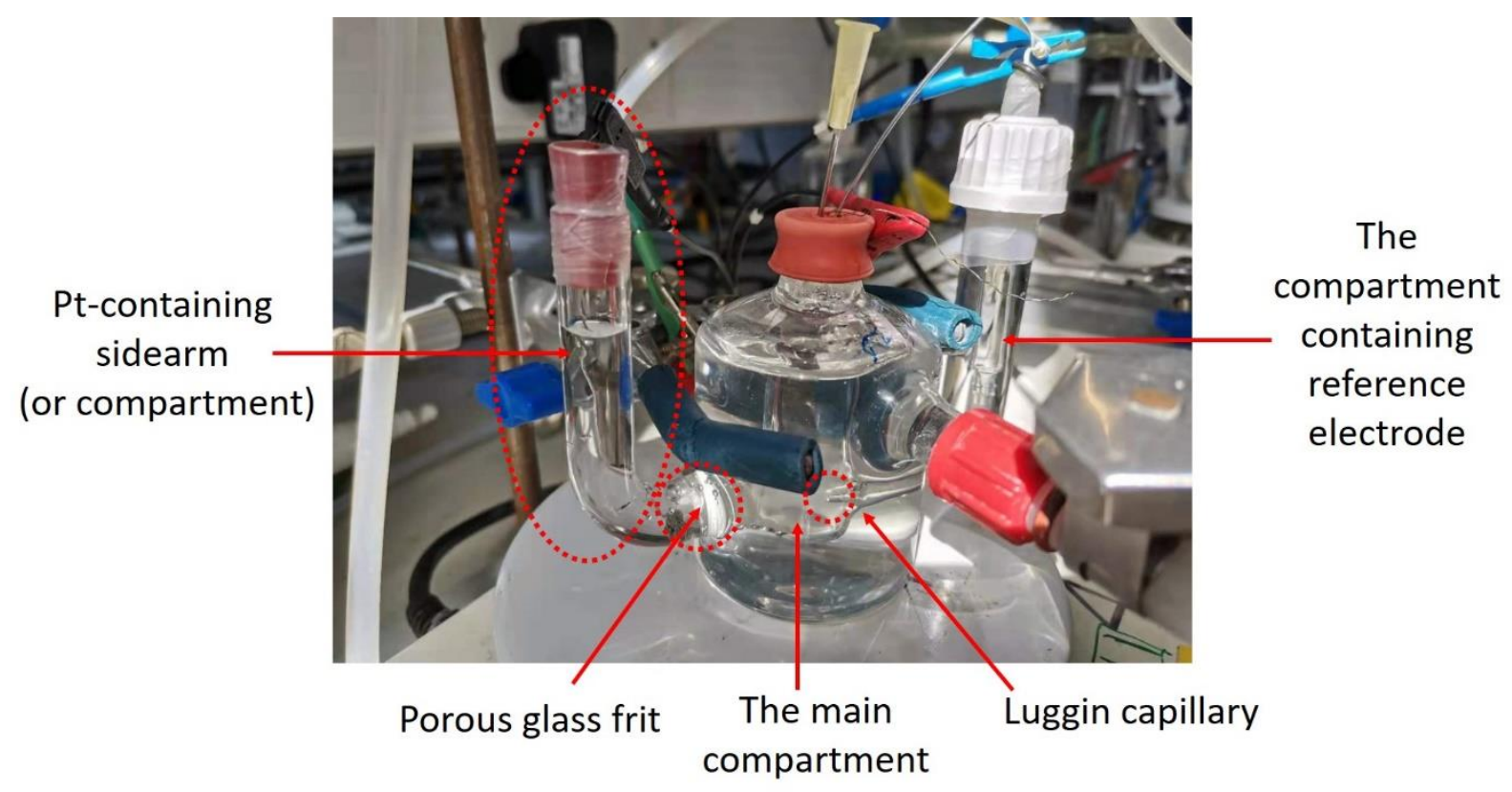

Figure S1 Photograph of the typical three-electrode set-up. The working electrode (FNR + ADH)@ITO/support is housed in the main compartment, which is separated from the side arm housing the Pt-counter electrode by a porous glass frit and from the reference-electrode-containing compartment by a Luggin capillary. 


\section{GC-FID (Chiral GC) Analysis, Protocol}

Conversions and enantiomeric excess (ee) were determined by GC-FID using a GC 6850 instrument fitted with an autosampler (Agilent) and a chiral BetaDex 325 column (30 m x 0.25 mm x $0.25 \mu \mathrm{m}$ ) (Supelco).

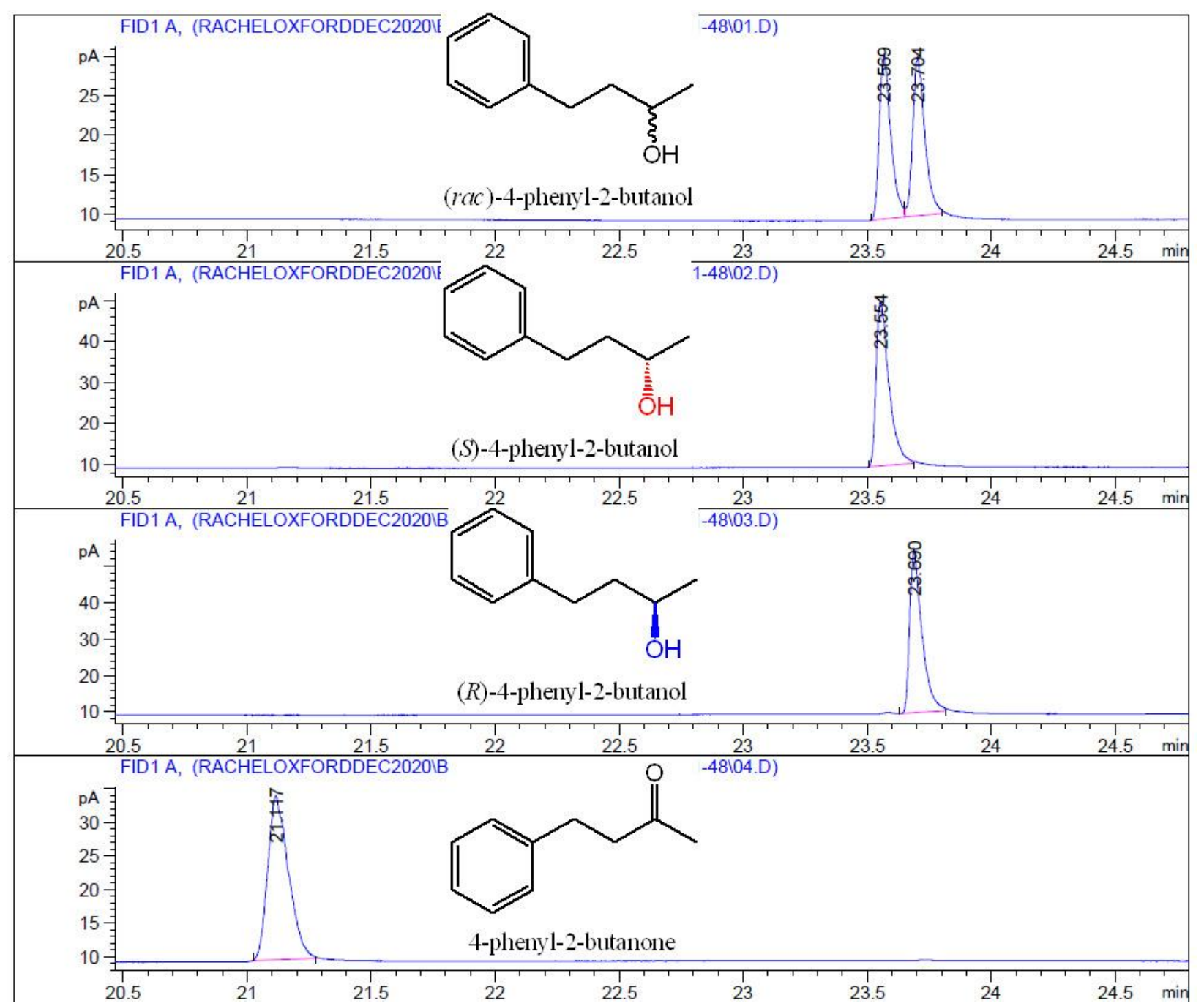

Figure S2 GC-FID results of standard solutions (from top to bottom): (rac)-4P2B, (S)-4P2B, (R)-4P2B and 4phenyl-2-butanone. Protocol: inlet temperature $200^{\circ} \mathrm{C}$, detector temperature $250{ }^{\circ} \mathrm{C}$, oven $110^{\circ} \mathrm{C} /$ hold 20 mins; $10{ }^{\circ} \mathrm{C} \mathrm{min}^{-1}$ to $200^{\circ} \mathrm{C}$. Rt (4-phenyl-2-butanone) $=20.8$ minutes, Rt $((R)-4 \mathrm{P} 2 \mathrm{~B})=23.6$ minutes, Rt $((S)-4 \mathrm{P} 2 \mathrm{~B})=23.4$ minutes. The concentration of $(\mathrm{rac})-,(S),(R)-4 \mathrm{P} 2 \mathrm{~B}$ and 4-phenyl-2-butanone in the stock solutions and samples are determined by $1 \mathrm{H}$ NMR (detailed analysis of NMR are shown later in this document). 


\section{Data for (FNR + TeSADH W110A)-catalyzed Reduction of 4-phenyl-2- butanone}
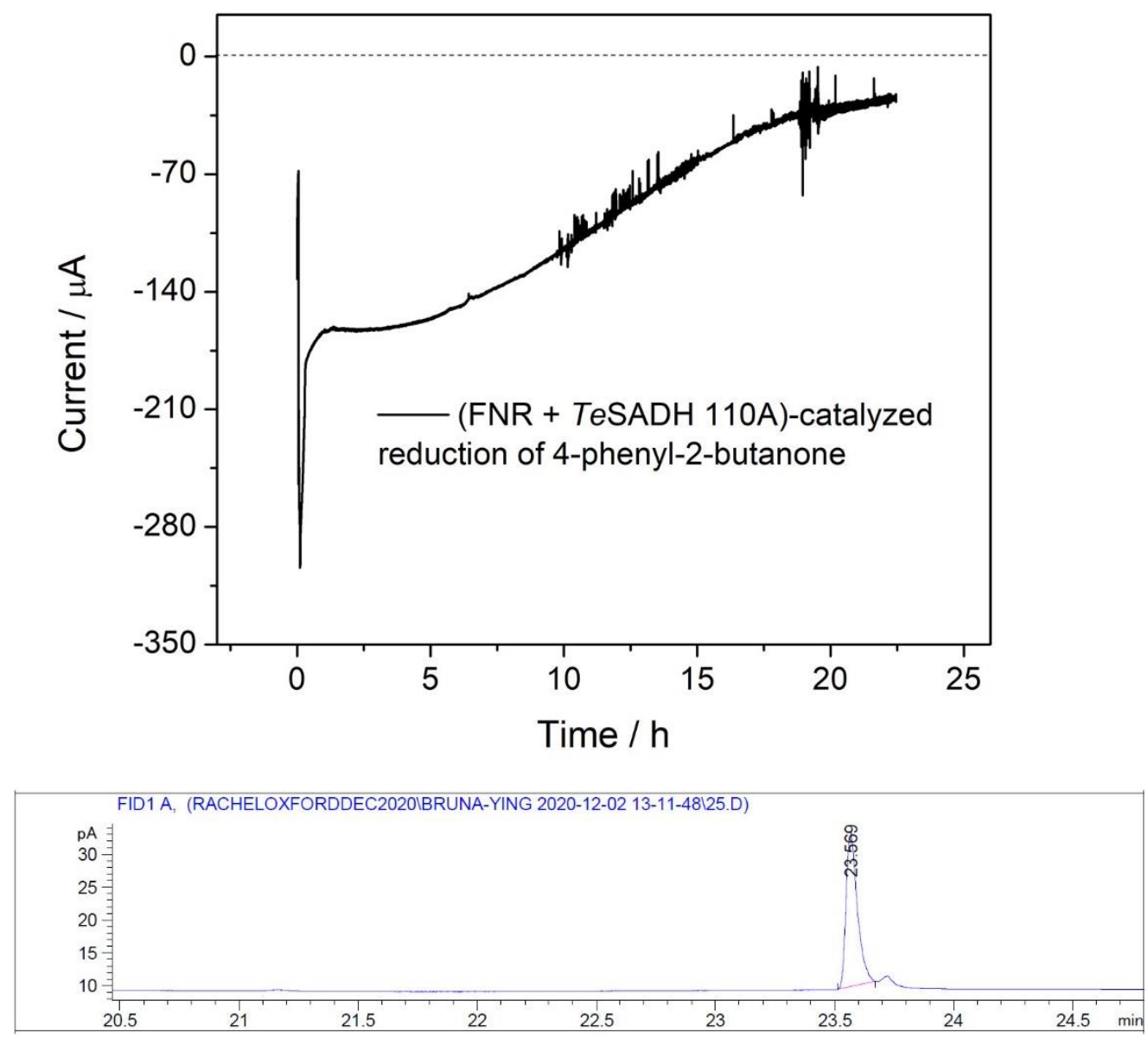

Figure S3 Upper: Chronoamperogram of 4-phenyl-2-butanone reduction. The experiment was catalyzed by a (FNR + TeSADH W110A)@ITO/Ti-foil electrode (active surface area $=7.2 \mathrm{~cm}^{2}$ ) which was prepared by placing the raw ITO/Ti-foil electrode into a vial containing dilute mixed FNR and TeSADH W110A (2.5 mL vial volume, $[\mathrm{FNR}]=4.96 \mu \mathrm{M},[$ TeSADH W110A $]=1.44 \mu \mathrm{M}, \mathrm{pH} 7.5,1 \mathrm{mM} \mathrm{MgCl}_{2}+50 \mathrm{mM}$ TAPS $+25 \mathrm{mM}$ $\mathrm{NaCl}$ ) in the cold room overnight, during which the solution was gently stirred. The electrode was thoroughly rinsed before use. Experimental conditions: cell volume $=4.02 \mathrm{~mL},\left[\mathrm{NADP}^{+}\right]=20 \mu \mathrm{M}$, [4phenyl-2-butanone] $=10.7 \mathrm{mM}, 25{ }^{\circ} \mathrm{C}$, applied reductive potential $=-0.649 \mathrm{~V}$ vs SHE. The FNR coverage on the electrode was approximately 51 pmole $\mathrm{cm}^{-2}$. Lower: GC-FID spectra, the ee after measurement is $89.1 \%(S)$ in the main compartment of the cell. 


\section{Data for (FNR + TeSADH W110A)-catalyzed Oxidation of (rac)-4P2B}
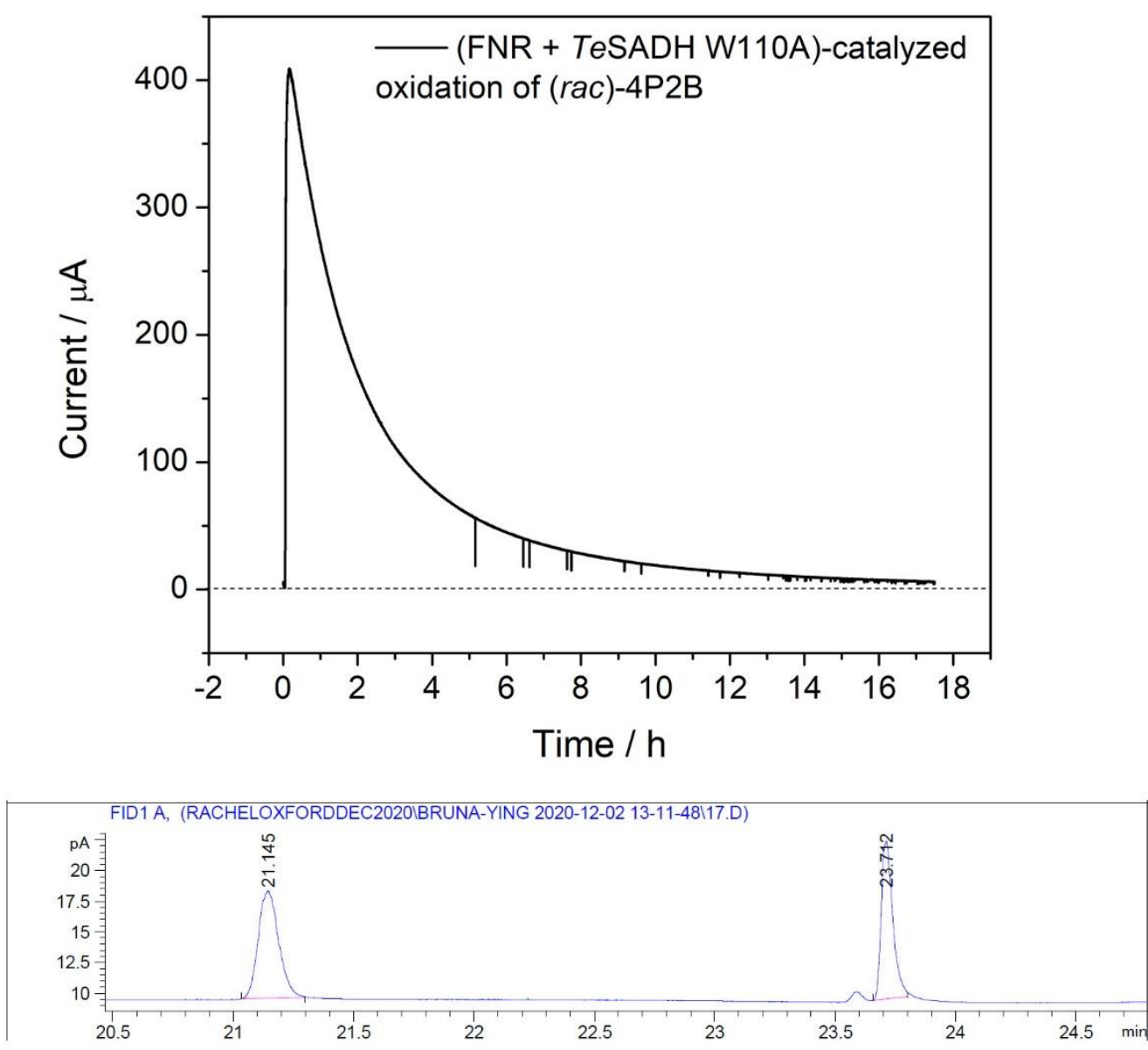

Figure S4 Upper: chronoamperogram of (rac)-4P2B oxidation. The experiment was catalyzed by a (FNR + TeSADHW110A)@ITO/Ti-foil electrode (active surface area $=7.2 \mathrm{~cm}^{2}$ ) which was prepared by placing the raw ITO/Ti-foil electrode into a vial containing dilute mixed FNR and TeSADH W110A (2.5 mL vial volume, $[\mathrm{FNR}]=3.72 \mu \mathrm{M},[$ TeSADH W110A $]=2.4 \mu \mathrm{M}, \mathrm{pH} 9.050 \mathrm{mM}$ TAPS $+1 \mathrm{mM} \mathrm{MgCl}_{2}$ buffer) in the cold room overnight, during which the solution was gently stirred. The electrode was thoroughly rinsed before use. Experimental conditions: cell volume $=4.02 \mathrm{~mL}$, $\left[\mathrm{NADP}^{+}\right]=20 \mu \mathrm{M},[(\mathrm{rac})-4 \mathrm{P} 2 \mathrm{~B}]=10.5 \mathrm{mM}, 25^{\circ} \mathrm{C}$, applied oxidative potential $=+0.071 \mathrm{~V}$ vs SHE. The FNR coverage on the electrode was approximately 101 pmole $\mathrm{cm}^{-2}$. The conversion from charge passed is $51.8 \%$. Lower: GC-FID spectra, the ee (main compartment) after measurement is $90.3 \%(R)$ (GC peak area (normalized to $4 \mathrm{~mL}$ as the standard cell volume): $(R)$ 45.6, (S) 2.3 , ketone 52.4 ; composition: $45.5 \%(R), 2.3 \%$ ketone, $52.2 \%(S)$ ). 


\section{Solution Assays of the TeSW110A-catalysed Racemization}

Table S1 Solution assays to observe the TeSW110A-catalyzed racemization process.

\begin{tabular}{|c|c|c|c|c|c|c|c|c|}
\hline No. & $\begin{array}{l}\text { [NADPH] } \\
/ \mathrm{mM}\end{array}$ & $\begin{array}{l}\left.\text { [NADP }^{+}\right] \\
/ \mathrm{mM}\end{array}$ & $\begin{array}{l}\text { [ADH] / } \\
n M\end{array}$ & Time / h & $\begin{array}{l}\text { Starting } \\
\text { isomer }\end{array}$ & $\begin{array}{c}\text { GC peak } \\
\text { Integral } \\
\text { (S) }\end{array}$ & $\begin{array}{l}\text { GC peak } \\
\text { integral } \\
(\mathrm{R})\end{array}$ & ee / \% \\
\hline 1 & 10 & 10 & 1,200 & 24 & $R$ & 22.3 & 124.4 & $69.6(\mathrm{R})$ \\
\hline 2 & 10 & 10 & 12 & 24 & $R$ & 1.4 & 141.5 & $98.0(R)$ \\
\hline 3 & 10 & 10 & 1,200 & 24 & $S$ & 108.1 & 28.9 & $57.8(\mathrm{~S})$ \\
\hline 4 & 10 & 10 & 12 & 24 & $S$ & 126.2 & - & > 99 (S) \\
\hline
\end{tabular}

Experimental conditions: $\mathrm{T}=24-28{ }^{\circ} \mathrm{C}, 1 \mathrm{~mL}$ cell solution in an Eppendorf tube, tubes were attached to a large flask and continuously mixed by placement in a shaking incubator set to $250 \mathrm{rpm}$. Buffer $=50 \mathrm{mM}$ TAPS, $1 \mathrm{mM}$ $\mathrm{MgCl}_{2}$, pH 9.0. [(S)-4P2B $]=9.4 \mathrm{mM}$ and $[(R)-4 \mathrm{P} 2 \mathrm{~B}]=10.2 \mathrm{mM}$. 


\section{Data for (FNR + ADH LK)-catalyzed Electrochemical Reduction of 4- phenyl-2-butanone}
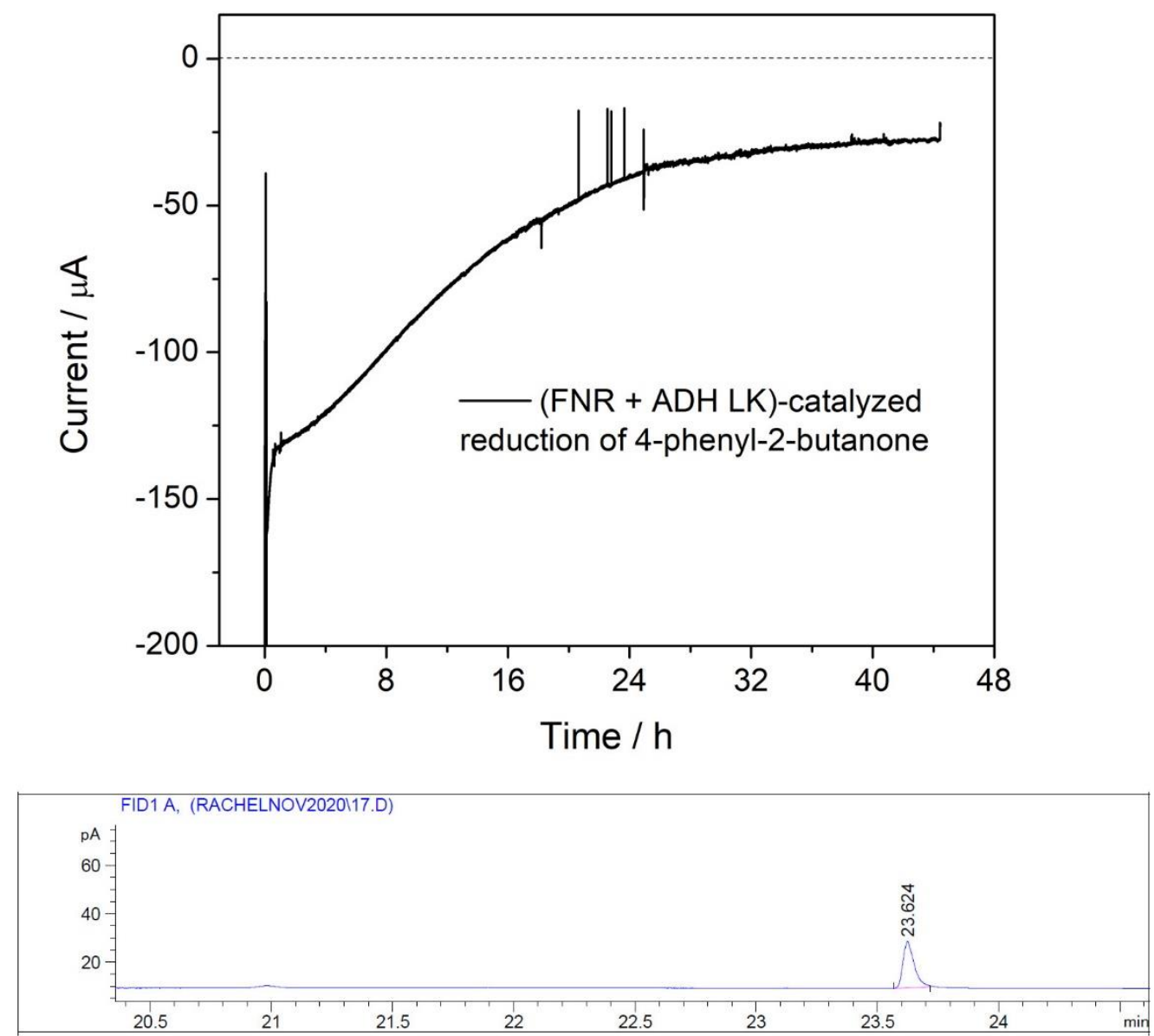

Figure S5 Upper: chronoamperogram of 4-phenyl-2-butanon reduction. The experiment was catalyzed by a (FNR+ADH LK)@ITO/Ti-foil electrode (active surface area $=7.2 \mathrm{~cm}^{2}$ ) which was prepared by dropcasting $10 \mu \mathrm{L}$ of a concentrated mixture containing FNR $(310 \mu \mathrm{M})$ and ADH LK (47 $\mu \mathrm{M})$ onto the raw ITO/Ti-foil electrode. This electrode was stored in a vial (placed on ice) for $40 \mathrm{~min}$ to prevent the electrode from drying out. Then the electrode was rinsed with buffer $(\mathrm{pH} 7.5$ buffer $1 \mathrm{mM} \mathrm{MgCl} 2+50 \mathrm{mM}$ TAPS $+25 \mathrm{mM}$ $\mathrm{NaCl}$ ) before use to ensure complete removal of unbound enzyme. Experimental conditions: cell volume $=4.02 \mathrm{~mL},\left[\mathrm{NADP}^{+}\right]=50 \mu \mathrm{M}$, [4-phenyl-2-butanone $]=10.7 \mathrm{mM}, 25{ }^{\circ} \mathrm{C}$, applied reductive potential = $-0.649 \mathrm{~V}$ vs SHE. The FNR coverage of as-prepared electrode was approximately 41 pmole $\mathrm{cm}^{-2}$. Lower: GC-FID spectra, the ee after measurement is almost $>99 \%(R)$ and the unreacted ketone accounts for $c a$. $7 \%$ of (alcohol + ketone) in the main compartment of the cell. 


\section{Data for (FNR + ADH LK)-catalyzed Oxidation of (rac)-4P2B}
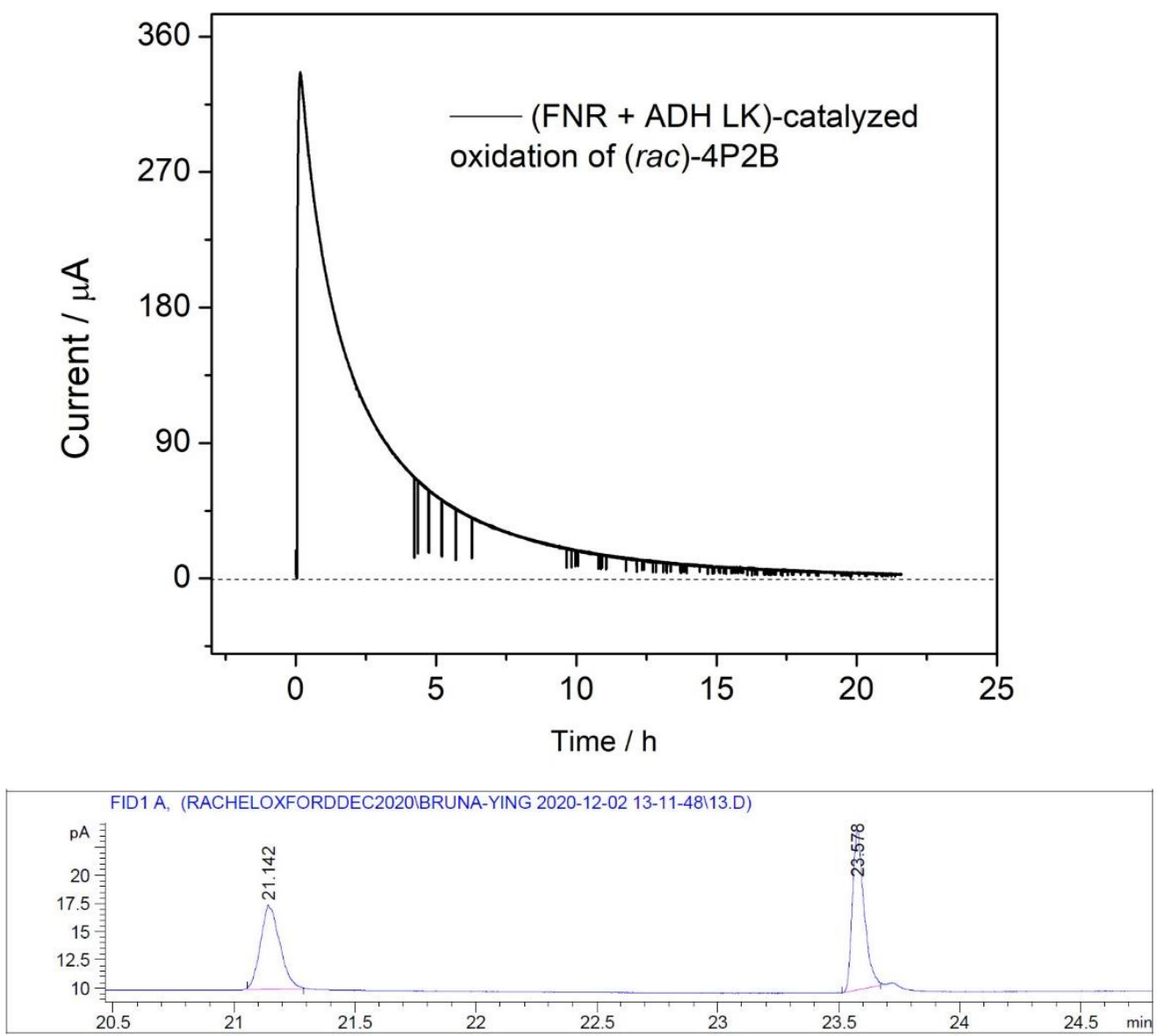

Figure S6 Upper: chronoamperogram of (rac)-4P2B oxidation. The experiment was catalyzed by a (FNR + ADH LK)@ITO/Ti-foil electrode (active surface area $=7.2 \mathrm{~cm}^{2}$ ) which was prepared by placing the raw ITO/Ti-foil electrode into a vial containing dilute mixed FNR and ADH LK (vial volume $2.5 \mathrm{~mL}$, [FNR] = 4.96 $\mu \mathrm{M},[\mathrm{ADH}$ LK $]=1.50 \mu \mathrm{M}, \mathrm{pH}$ 9.0, $50 \mathrm{mM}$ TAPS $+1 \mathrm{mM} \mathrm{MgCl}_{2}$ buffer) in the cold room overnight, during which the solution was gently stirred. The electrode was rinsed thoroughly before use. Experimental conditions: cell volume $=4.02 \mathrm{~mL},\left[\mathrm{NADP}^{+}\right]=50 \mu \mathrm{M},[(\mathrm{rac})-4 \mathrm{P} 2 \mathrm{~B}]=9.7 \mathrm{mM}, 25^{\circ} \mathrm{C}$, applied oxidative potential $=+0.071 \mathrm{~V}$ vs SHE. The FNR coverage of this as-prepared electrode was approximately 156 pmole $\mathrm{cm}^{-2}$. The conversion from charge passed is $45.1 \%$. Lower: GC-FID spectra, the ee (main compartment) after measurement is $93.1 \%(S)$ (GC peak area (normalized to $4 \mathrm{~mL}$ ): $(R)$ 1.8, $(S)$ 50.4, ketone 42.6, composition: $1.9 \%(\mathrm{R}), 53.2 \%(\mathrm{~S}), 44.9 \%$ ketone). 


\section{Data for (FNR + TeSADH W110V)-catalyzed Reduction of 4-phenyl-2- butanone}
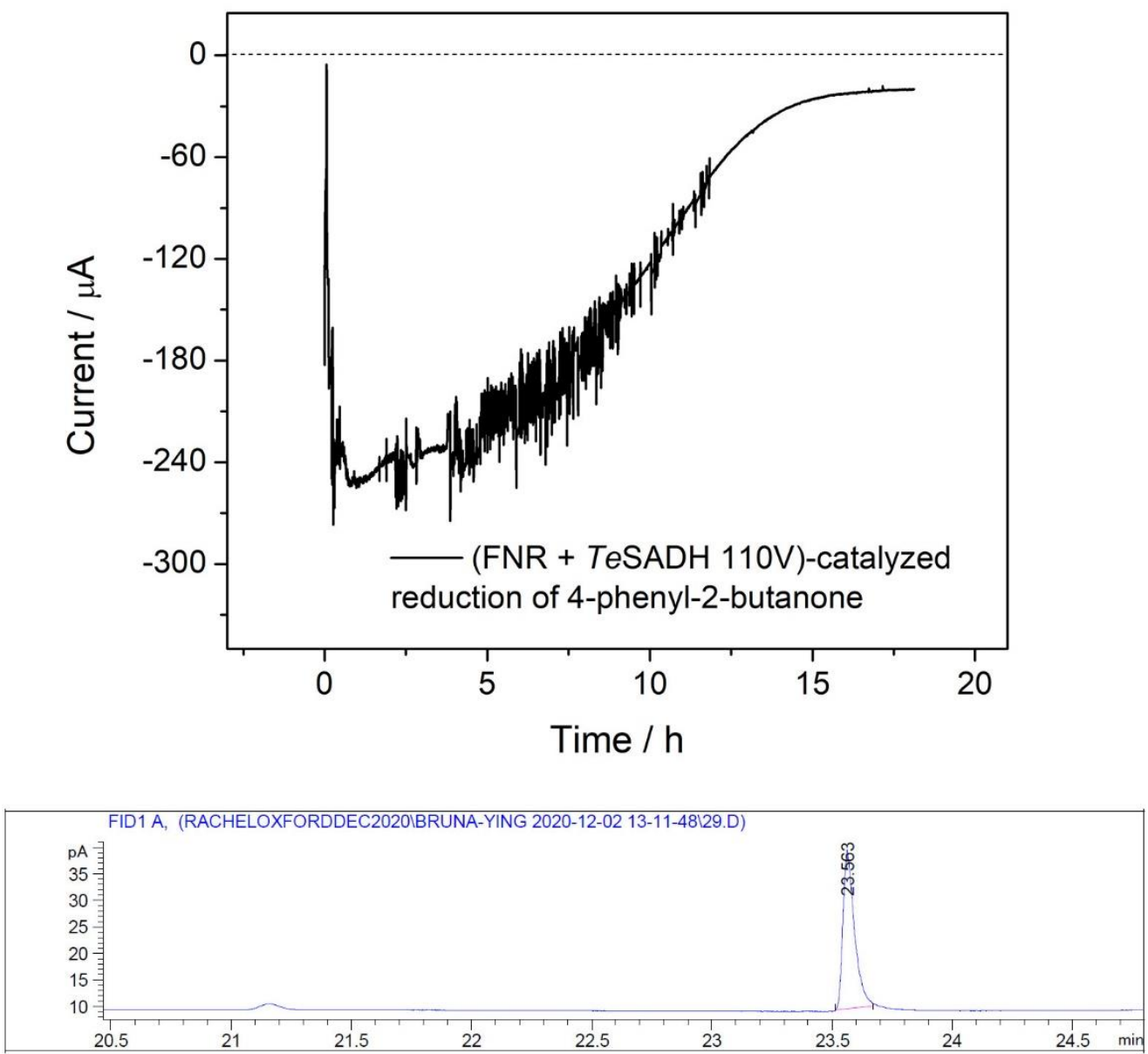

Figure S7 Upper: Chronoamperogram of 4-phenyl-2-butanone reduction. The experiment was catalyzed by a (FNR + TeSADH W110V)@ITO/Ti-foil electrode (active surface area $=7.2 \mathrm{~cm}^{2}$ ) which was prepared by placing the raw ITO/Ti-foil electrode into a vial containing dilute mixed FNR and TeSADH W110V (vial volume $2.5 \mathrm{~mL},[\mathrm{FNR}]=3.72 \mu \mathrm{M},[$ TeSADH W110V] $=1.3 \mu \mathrm{M}, \mathrm{pH} 7.51 \mathrm{mM} \mathrm{MgCl}+50 \mathrm{mM}$ TAPS $+25 \mathrm{mM}$ $\mathrm{NaCl}$ ) in the cold room overnight, during which the solution was gently stirred. The electrode was rinsed thoroughly before use. Experimental conditions: cell volume $=4.02 \mathrm{~mL}$, [NADP $]=50 \mu \mathrm{M}$, [4-phenyl-2butanone] $=10.7 \mathrm{mM}, 25{ }^{\circ} \mathrm{C}$, applied reductive potential $=-0.649 \mathrm{~V}$ vs SHE. The FNR coverage on the electrode was approximately 49 pmole $\mathrm{cm}^{-2}$. Lower: GC-FID spectra, the ee (main compartment) after 
measurement is $>99 \%(S)$ and the unreacted ketone accounts for ca. $5.1 \%$ of (alcohol + ketone) in the main compartment of the cell.

\section{${ }^{1} \mathrm{H}$ NMR Analysis}

\section{Protocol}

${ }^{1} \mathrm{H}$ NMR is exploited to quantify the concentrations of $(S)$ - and $(R)-4 \mathrm{P} 2 \mathrm{~B}$. A sample comprises by cell solution and $\mathrm{D}_{2} \mathrm{O}$ in 90:10 ratio (total volume $=600 \mathrm{~mL}$ ). The ${ }^{1} \mathrm{H}$ NMR measurement was carried out using a Bruker AVIIIHD 400 instrument with the water suppression (unlock) mode. Concentration of samples is determined by comparing the relative ratio between integral area of the peaks corresponding to the compound of interest (here, mainly 4-phenyl-2-butanol) and those corresponding to the solution of the internal standard 3-(Trimethylsilyl)propionic-2,2,3,3-d4 acid sodium salt (TMSP) of known concentration $(1.16 \mathrm{mM})$. The chemical shift $(\delta)$ in the spectra shown in this paper is around $-0.1 \mathrm{ppm}$, with $9 \mathrm{H}$. The standard solution of TMSP is contained in a sealed thin capillary tube which is placed into the NMR tube together with the sample for measuring.

The equation for calculating the concentration of sample is as follows:

$$
\frac{A /(\text { the number of } \mathrm{H} \text { corresponding to } A)}{B / 9} \times 1.16
$$

Where $A=$ integral area of all characteristic peaks involved for the compound in interest, $B=$ integral area of the peaks for TMSP, and $1.16(\mathrm{mM})$ is the concentration of TMSP. 


\section{TAPS Buffer}

In this paper, the substrates are all dissolved in $50 \mathrm{mM}$ TAPS buffer. Therefore, to quantify the alcohol after measurement and avoid the signal being convoluted by the buffer, it is important to obtain the ${ }^{1} \mathrm{H}$ NMR spectra for TAPS buffer. Also, the chemical shifts of peaks corresponding to TAPS buffer vary with $\mathrm{pH}$, so the NMR spectra of TAPS buffer at $\mathrm{pH} 7.5$ and $\mathrm{pH} 9.0$ are both shown for reference.

\section{TAPS buffer, pH 9.0}

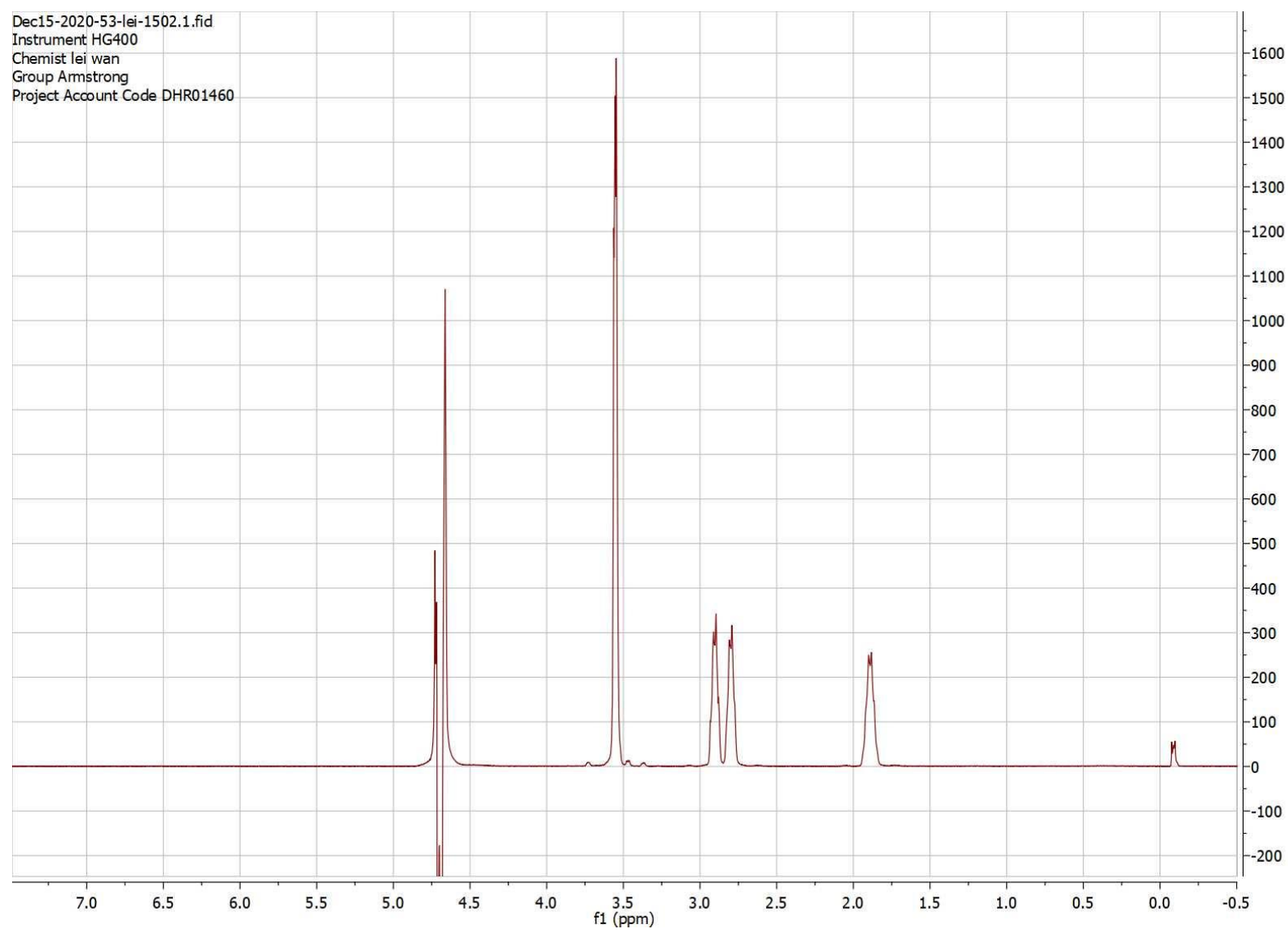

Figure S8 ${ }^{1} \mathrm{NMR}$ spectra for $50 \mathrm{mM}$ TAPS buffer at $\mathrm{pH} 9.0$ (dissolved $1 \mathrm{mM} \mathrm{MgCl}$ ) 
TAPS buffer, pH 7.5

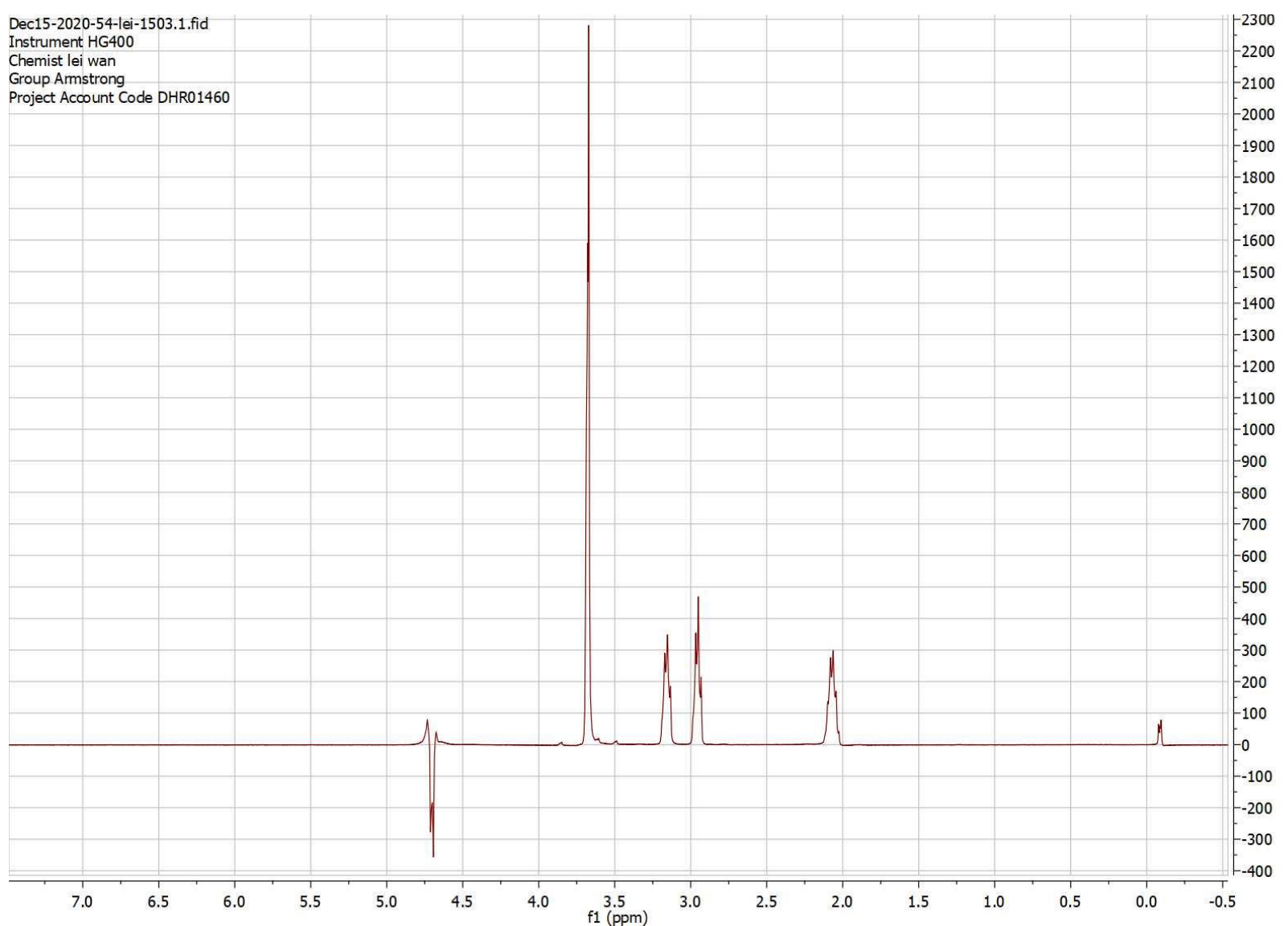

Figure S9 ${ }^{1} \mathrm{NMR}$ spectra for $50 \mathrm{mM}$ TAPS buffer at $\mathrm{pH} 7.5$ (dissolved with $25 \mathrm{mM} \mathrm{NaCl}+1 \mathrm{mM} \mathrm{MgCl}$ ) 


\section{Standard Solution of 4-phenyl-2-butanol in TAPS Buffer at pH 9.0}

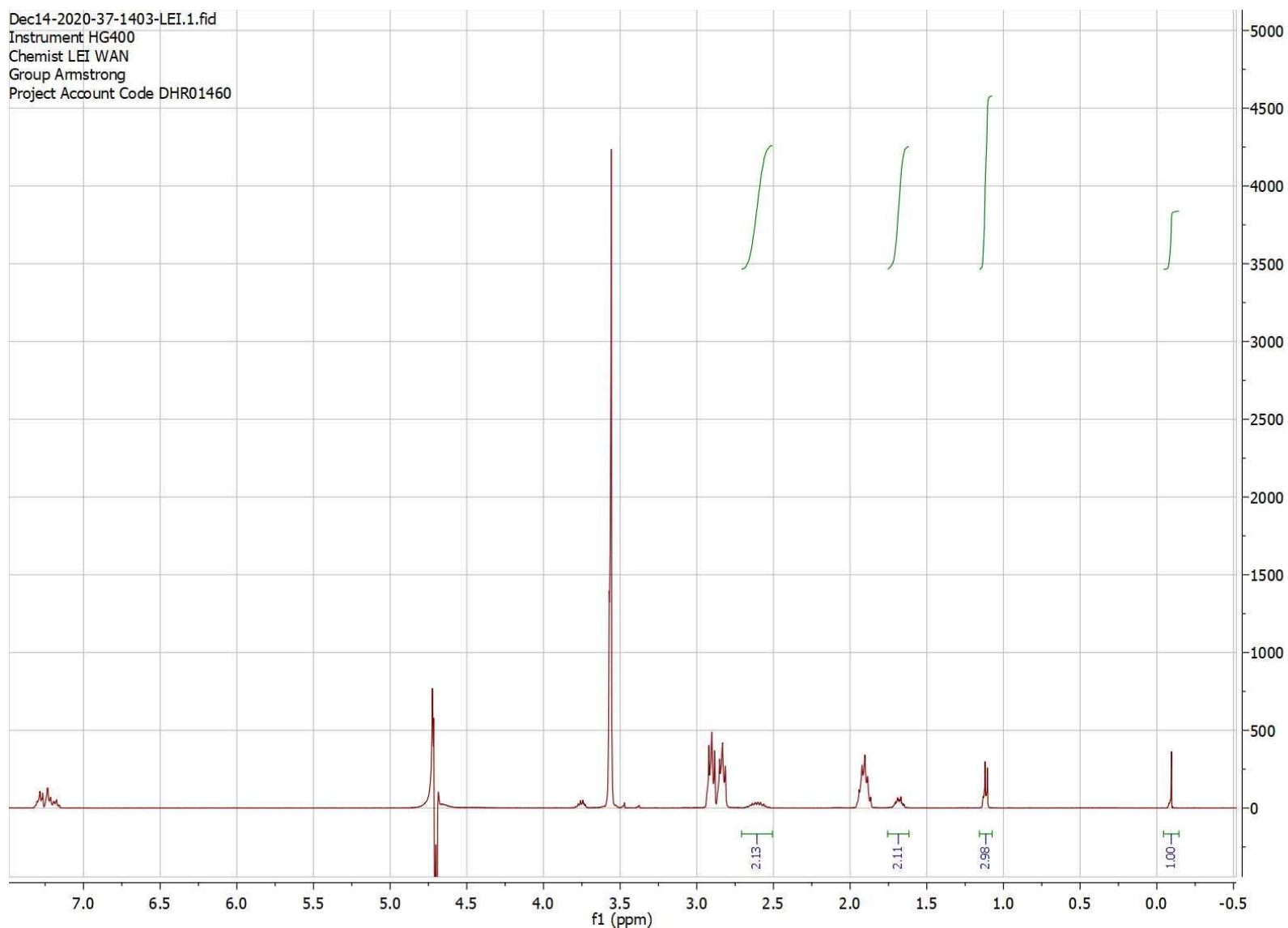

Figure S10 ${ }^{1} \mathrm{NMR}$ spectra for $(\mathrm{rac})-4 \mathrm{P} 2 \mathrm{~B}(10.7 \mathrm{mM})$ at pH 9.0 in TAPS buffer (50 mM $\left.11 \mathrm{mM} \mathrm{MgCl} 2\right)$. The peaks around $\delta 1.2(\mathrm{~m}, 3 \mathrm{H}), \delta 1.7(\mathrm{~m}, 2 \mathrm{H}), \delta 2.6(\mathrm{~m}, 2 \mathrm{H})$, and $\delta 7.2(\mathrm{~m}, 5 \mathrm{H})$ correspond to $\mathrm{H}$ on the methyl, two methylene groups and the benzyl group of 4P2B, respectively. However, after the electrochemical experiments, the peaks around $\delta 7.2(\mathrm{~m}, 5 \mathrm{H})$ are convoluted with the results of 4-phenyl-2-butanone. Therefore, in this paper, only the peaks around $\delta 1.2(\mathrm{~m}, 3 \mathrm{H}), \delta 1.7(\mathrm{~m}, 2 \mathrm{H}), \delta 2.6(\mathrm{~m}, 2 \mathrm{H})$ are exploited for quantifying 4P2B. 


\section{Data for De-racemizer to Produce $(R)-4$ P2B}

These results correspond to the experiment described in Figure 3C.

\section{GC-FID}

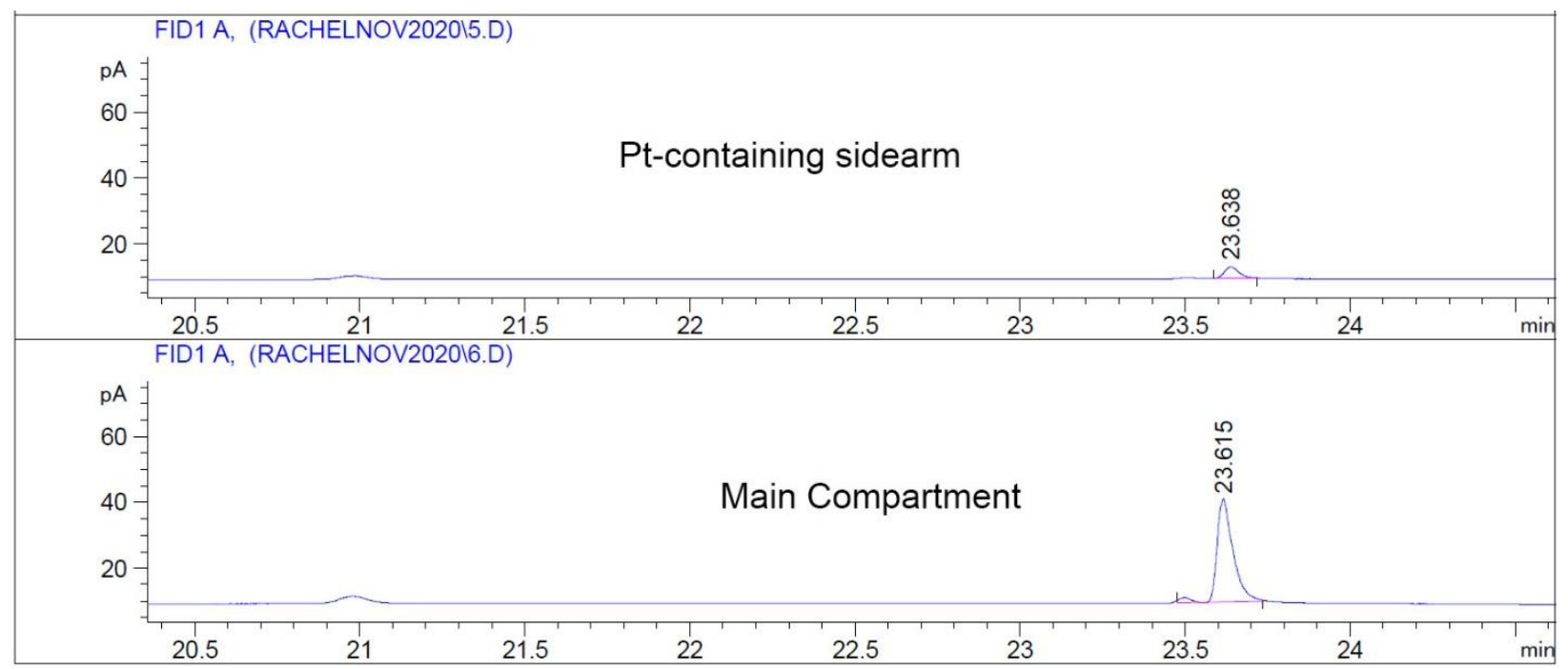

Figure S11 GC-FID spectra for the sample collected in the main and Pt-containing compartments. This figure corresponds to the experiment described in Figure 3C. 


\section{${ }^{1} \mathrm{H}$ NMR}

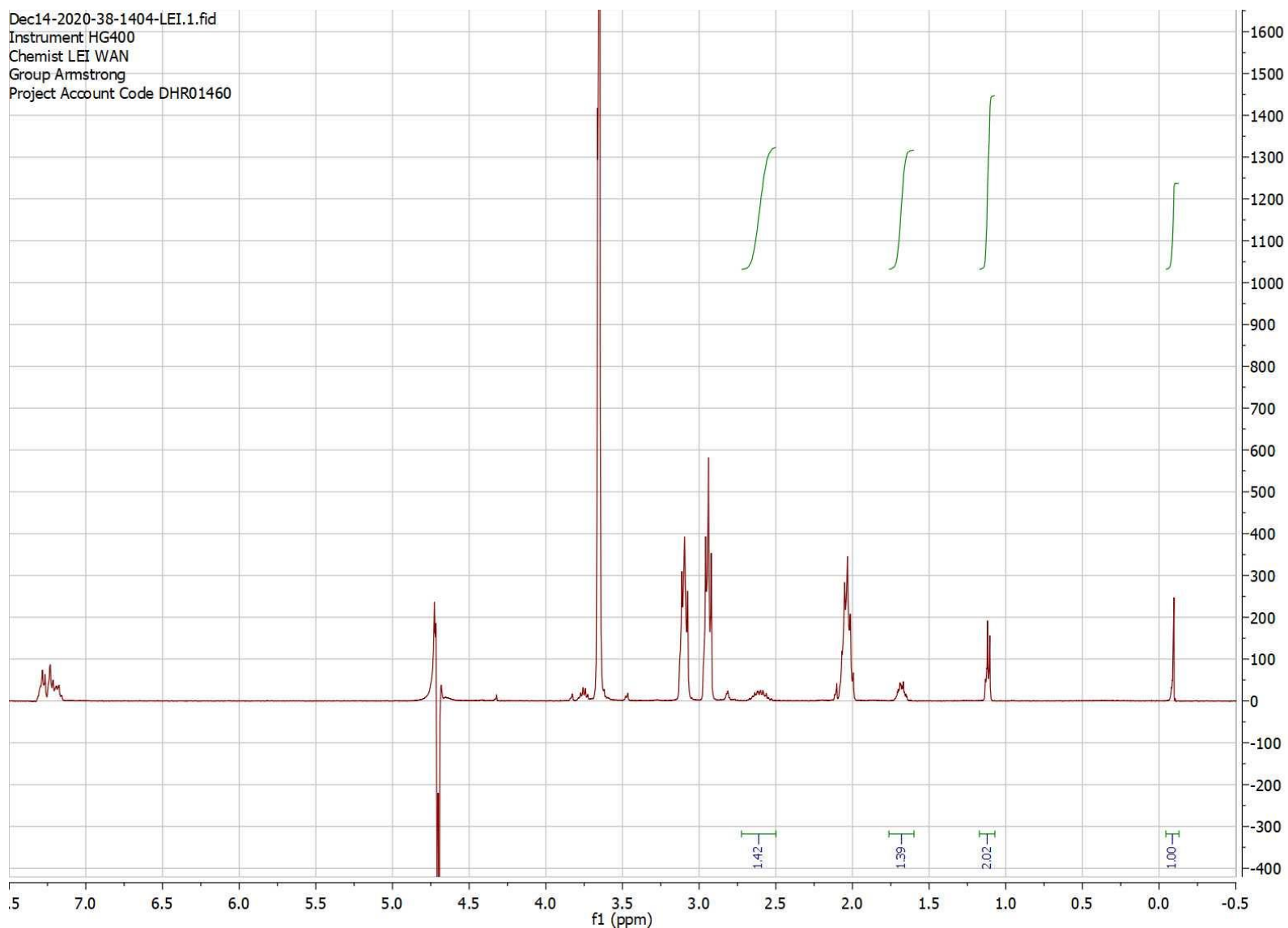

Figure S12 ${ }^{1} \mathrm{H}$ NMR spectra for the sample collected in the main compartment. The peaks around $\delta 1.2$ $(\mathrm{m}, 3 \mathrm{H}), \delta 1.7(\mathrm{~m}, 2 \mathrm{H}), \delta 2.6(\mathrm{~m}, 2 \mathrm{H})$ correspond to 4P2B which are not convoluted with TAPS buffer and 4-phenyl-2-butanone. The peaks around $\delta-0.1(\mathrm{~m}, 9 \mathrm{H})$ correspond to the internal standard TMSP (ca. $1.16 \mathrm{mM}$ ). After the CA experiment, the cell volume expands to $4.15 \mathrm{~mL}$, so the [4P2B] should expand by $(4.15 / 4) * 100 \%$ from the concentration calculated accordingly. This figure corresponds to the experiment described in Figure 3C. 


\section{Data for De-racemizer to Produce (S)-4P2B}

These results correspond to the experiment described in Figure 4C.

\section{GC-FID}

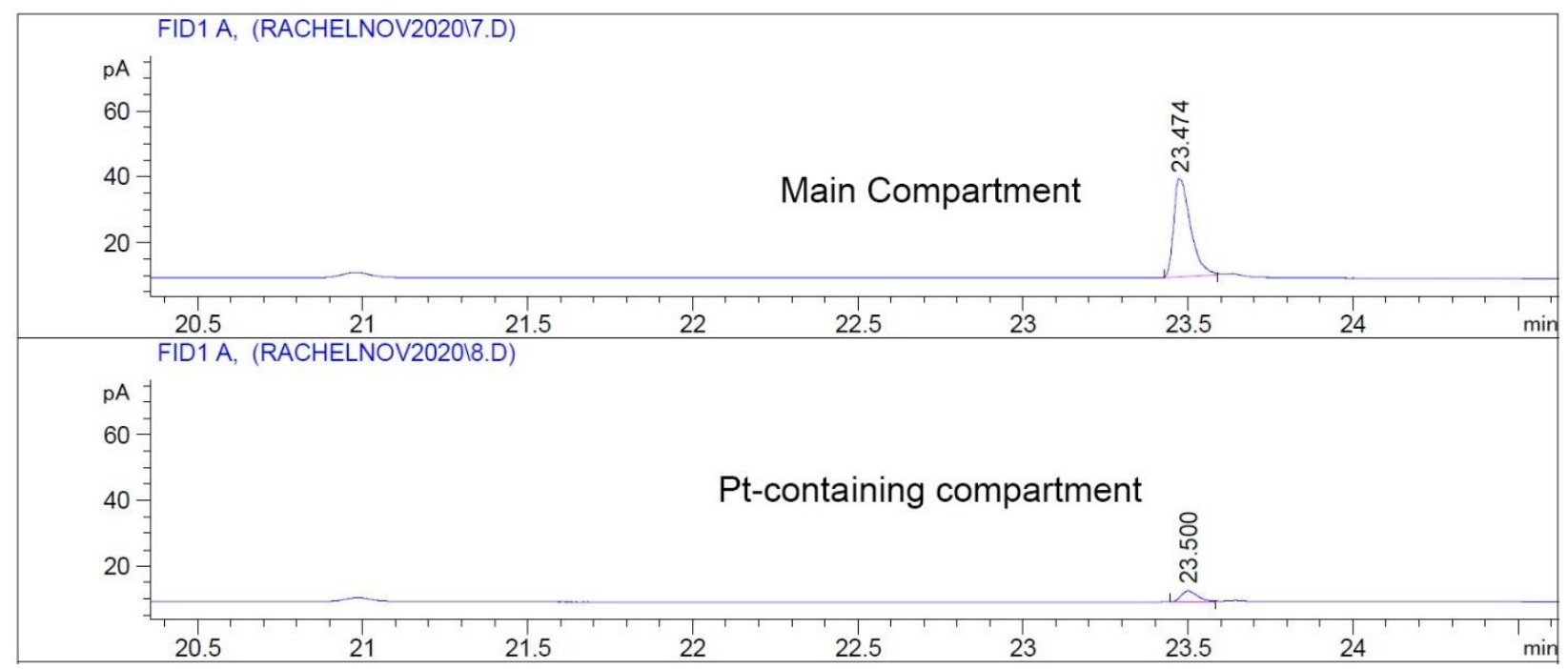

Figure S13 GC-FID spectra for the sample collected in the main and Pt-containing compartments. This figure corresponds to the experiment described in Figure 4C. 


\section{${ }^{1} \mathrm{H}$ NMR}

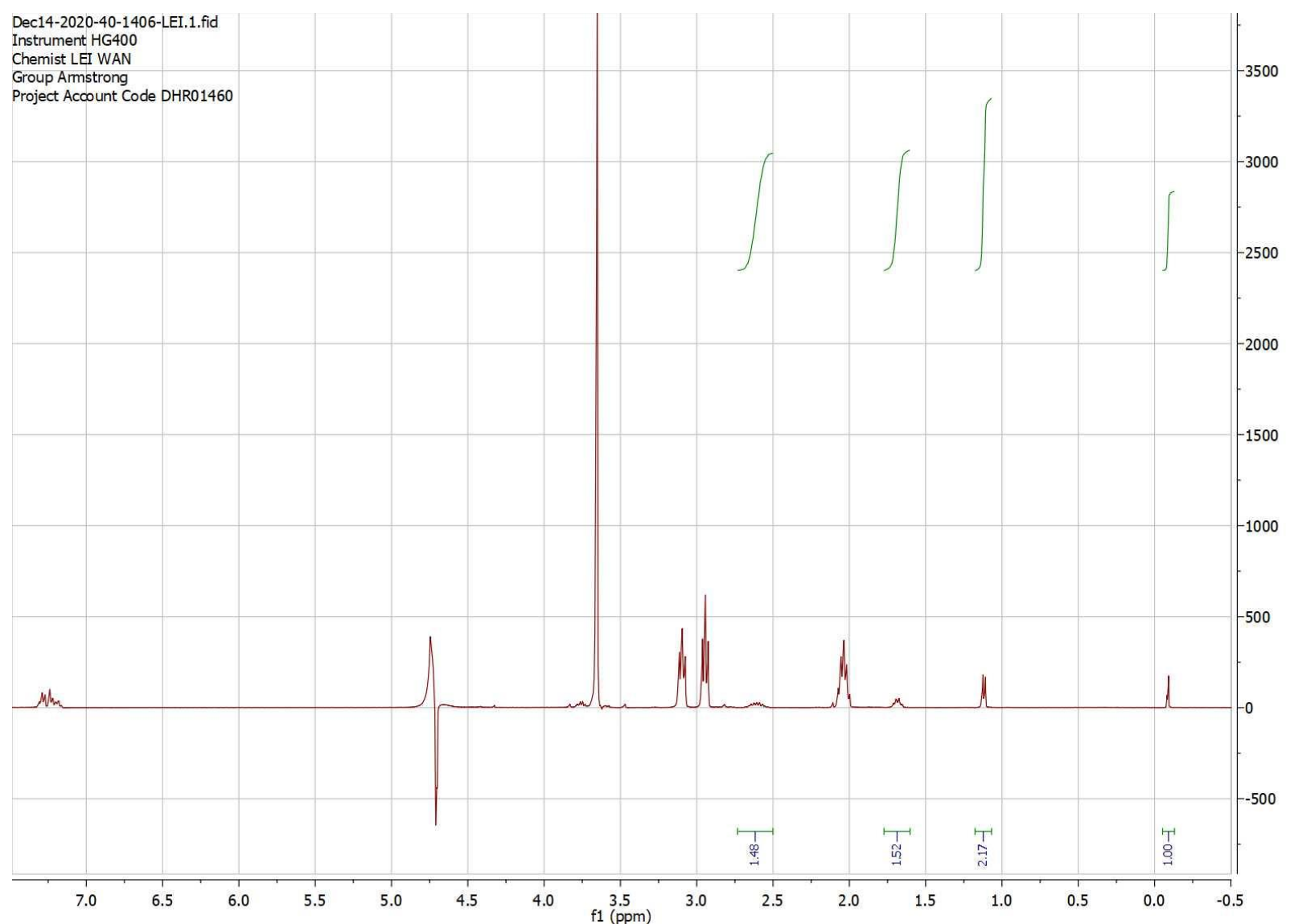

Figure S14 ${ }^{1} \mathrm{H}$ NMR spectra for the sample collected in the main compartment. The peaks around $\delta 1.2$ $(\mathrm{m}, 3 \mathrm{H}), \delta 1.7(\mathrm{~m}, 2 \mathrm{H}), \delta 2.6(\mathrm{~m}, 2 \mathrm{H})$ correspond to 4P2B and not convoluted with TAPS buffer and 4phenyl-2-butanone. The peaks around $\delta-0.1(\mathrm{~m}, 9 \mathrm{H})$ correspond to the internal standard TMSP (ca. 1.16 $\mathrm{mM}$ ). After the CA experiment, the cell volume expands to $4.10 \mathrm{~mL}$, so the [4P2B] should expand by $(4.10 / 4) * 100 \%$ from the concentration calculated accordingly. This figure corresponds to the experiment described in Figure 4C. 


\section{REFERENCES}

(1) Megarity, C. F.; Siritanaratkul, B.; Heath, R. S.; Wan, L.; Morello, G.; FitzPatrick, S. R.; Booth, R. L.; Sills, A. J.; Robertson, A. W.; Warner, J. H.; Turner, N. J.; Armstrong, F. A. Electrocatalytic volleyball: rapid nanoconfined nicotinamide cycling for organic synthesis in electrode pores, Angew. Chem. Int. Ed. 2019, 58, 4948-4952.

(2) Weckbecker, A.; Hummel, W. Cloning, expression, and characterization of an (R)specific alcohol dehydrogenase from Lactobacillus kefir, Biocatal. Biotransformation 2006, 24, 380-389.

(3) Cornish-Bowden, A. Fundamentals of enzyme kinetics; John Wiley \& Sons, 2013.

(4) Wan, L.; Megarity, C. F.; Siritanaratkul, B.; Armstrong, F. A. A hydrogen fuel cell for rapid, enzyme-catalysed organic synthesis with continuous monitoring, Chem. Commun. 2018, $54,972-975$.

(5) Siritanaratkul, B.; Megarity, C. F.; Roberts, T. G.; Samuels, T. O.; Winkler, M.; Warner, J. H.; Happe, T.; Armstrong, F. A. Transfer of photosynthetic NADP+/NADPH recycling activity to a porous metal oxide for highly specific, electrochemically-driven organic synthesis, Chem. Sci. 2017, 8, 4579-4586. 